проф. д-р Пол Степни

Школа за хуманистички и општествени науки

Тампере Универзитет, Финска

\title{
СТАРИТЕ ЛИЦА ВО СЕНКА НА ПАЗАРНАТА СОЦИЈАЛНА ГРИЖА: ЕВРОПСКИ СОЦИЈАЛНИ МОДЕЛИ, ДИЛЕМИ И ПРЕДИЗИЦИ ЗА ПОЛИТИКАТА И ПРАКСАТА ВО ОДНОС НА КРИЗАТА НА ДОЛГОРОЧНАТА НЕГА
}

\section{Апстракт}

Севкупната криза на системот на долгорочна нега сурово излезе на виделина со неодамнешното ширење на корона вирусот низ цела Европа, истакнувајќи ја ранливоста на постарите лица, особено оние во домовите за згрижување. Целта на оваа статија е да се открие природата на кризата во долгорочна нега, да се процени нејзиното влијание врз постарите луѓе и да се анализираат предизвиците со кои се соочуваат креаторите на политиките и практичарите. Обединетото Кралство е примарен фокус во оваа статија, бидејќи нејзините реформи во грижата во заедницата воспоставија репер за реформи во Европа. Оттука, нејзината мешана економија на обезбедување, отворен консумеризам и употреба на пазарот за да се ограничат трошоците ќе бидат предмет на критичко набљудување. Ке се спомене политиката во другите европски социјални држави и предизвиците покренати од неодамнешните извештаи на Европската Унија (ЕУ) за долгорочна нега, за да се задоволат потребите на стареењето на на- селението во Европа. Ќе бидат оценети различни модели на социјална заштита за да се утврди која рамка на политики обезбедува најефикасни и интегрирани услуги за грижа за ранливите постари граѓани. Дебатата ќе биде илустрирана со испитување на современи прашања што предизвикуваат загриженост, како што се: отпуштање од болница кај постари лица, дилеми за управување со ризици во пракса и ескалирање на трошоците за долгорочна нега. Во оваа статија е усвоен интерпретативен пристап кон производството на знаење со помош на извори на документи, вклучувајќи студии на случаи, официјални извештаи и емпириски истражувачки докази. Анализата не следи строг компаративен дизајн и претставува своевиден истражувачки есеј. Истиот открива дека додека фокусот на ризикот продолжува да ги обликува главните текови на праксата, истовремено се зголемува признавањето на потребата за развој на поопсежна долгорочна нега базирана на заедницата, со акцент на спречување и зајакнување. Постојат 
добри истражувачки докази за инвестирање во рехабилитација, интегрирано обезбедување и персонално заснована домашна нега за постари лица. Во таа насока, статијата завршува со препораки за праксата.

Клучни зборови: долготрајна грижа, постари лица, грижа во заедницата

\section{Вовед}

Целосниот обем на кризата во долгорочната нега беше сурово изложен на виделина со неодамнешното ширење на пандемијата на корона низ цела Европа, што ја истакна ранливоста на постарите лица, особено во домовите за нега. Жителите во домовите за нега во Обединетото Кралство беа изложени на вирусот Ковид-19 од постарите луѓе кои беа набрзина отпуштени од болница без да бидат тестирани. Помеѓу март и јуни 2020 година, стапката на смртност во домовите за згрижување брзо се зголеми, што доведе до повеќе од 16.000 смртни случаи (третина од сите жртви во Обединетото Кралство), што претставува сериозен неуспех во политиката за заштита на повеќето од најранливите постари луѓе во Обединетото Кралство (Бут и Данкан, 2020 година). Заедно со ова, постарите луѓе кои живеат во заедница се „штитат“ од дома со социјални услуги со кои можат да обезбедат само основна поддршка. Ова значи дека без пријатели или роднини да ги посетуваат, ниту во домовите за нега или во приватни живеалишта и со услуги сведени на минимум, со- цијалната изолација и осаменоста ја влошуваат и така веќе тешката состојба.

Кога ќе се анализира поддршката на постарите лица кои живеат во заедницата за разлика од онаа во домовите за нега, почнуваме да наоѓаме пообемна варијација. Низ цела Европа, помеѓу $50 \%$ и $75 \%$ од целата формална долгорочна нега е овозможена во заедницата (Евростат, 2018 година). Забележувајќи дека постои голема варијација во финансирањето, организацијата и испораката на услуги за грижа во заедницата, влијателен извештај на ЕУ за долгорочна нега (Спасова $u$ gp., 2018) идентификуваше четири проблеми ширум Европа:

- проблеми со пристапот и соодветноста на одредбата за долгорочна нега

- прашања што се однесуваат на негувателите

- проблеми во врска со квалитетот на обезбедувањето

- долгорочна финансиска одржливост.

Овие проблеми претставуваат предизвик за сите земји членки на ЕУ и ќе треба да се најдат решенија за прогресивна политика доколку се сака тековната криза во долгорочната нега да се реши и ефикасно да се управува (Спасова $u$ сор., 2018 година).

Со оглед на широките варијации низ Европа, дефиниција на клучните термини може да биде корисна. Секторот за домови за нега се состои од 
резиденцијални домови за стари лица и негувателски домови за стари лица. Негувателските домови се за постари лица кои се оценети од квалификувана медицинска сестра или лекар дека имаат поголема здравствена потреба. Покрај тоа, широкиот сеопфатен термин за јавна здравстена нега може да се дефинира како „мрежа на нега што ќе ги одржува луѓето или ќе ги врати луѓето во независно живеење ... со што ќе им овозможи да живеат во своите домови“ (Центар за политика за стареење, 1990, стр. 16). Негата обично е организирана од страна на професионалци за социјална работа и здравствена заштита по направена проценка водена од потребите и испорачана од низа на персонал за нега. Негата обично вклучува домашна нега (пазарување, чистење, домаќинство и така натаму) и евентуално лична нега, како и за оние со поголемо ниво на зависност (помош при секојдневно живеење, како што е миење, легнување и стаанување од кревет, облекување, хранење и одење во тоалет).

Во оваа статија, наспроти позадината на тековната пандемија на корона, ќе се анализира влијанието на тековната криза во долгорочната нега за постарите лица. Мешаната економија на пазарот за обезбедување и грижа во Обединетото Кралство ќе биде примарен фокус и ќе биде предмет на критичко надгледување, вклучувајќи ги конфликтите, противречностите и поделбите својствени на политиката. Ке се направи упатување на политиката во другите европски социјални држави и четирите предизвици покренати од извештајот на ЕУ за долгорочна нега (Спасова и сор., 2018), вклучувајќи го и секако демографскиот предизвик за задоволување на потребите на растечкото старо население во Европа. Едно од клучните прашања се однесува на тоа кој европски социјален модел ја обезбедува најкорисната рамка за политика за обезбедување ефективни и интегрирани услуги за грижа за ранливите постари граѓани. Дебатата ќе биде илустрирана со испитување на актуелни прашања што загрижуваат, вклучително и отпуштањето од болница на постарите лица, дилеми за управување со ризиците во пракса и ескалирањето на трошоците за долгорочна нега. Конечно, написот ќе заврши со идентификување на клучните трендови и поврзување на анализата на политиката со кратки препораки за пракса.

\section{Предизвикот на староста заедно со новонастанатата криза во грижата}

Староста е концепт што разбирливо предизвикува силни чувства кај нас - како ќе биде кога ќе остариме, како ќе се справиме особено ако нашето здравје започне да се влошува и кој ќе се грижи за нас? Важно е како ќе бидеме третирани во општеството - како мудар и почитуван старец, како Индијанците од Омаха, во Северна Америка или ќе бидеме гледани како товар на државата и непријатност што треба да се фрли настрана и да се заборави во 
некои безлични институционални социјални складишта? Песната на Битлси, „Кога сум шеесет и четири“, напишана од Ленон-Меккартни и снимена во 1967 година, ги доловува стравувањата од староста:

Коїа ќе остиарам, ќе ја изіуубам косайа, мноту їо gини оg сеїа... Дали ушиее ке тии ииребам, gали сѐ ушйе ќе ме храниш коїа ќе имам шеесей и четиири

Авторско право: Northern Songs LTD (1967 година)

Без оглед на концептуализацијата на староста, јасно е дека побарувачката за здравствена и социјална заштита ќе се зголеми експоненцијално во секоја европска земја во следните 50 години (Европската комисија, 2018 година). Постои очекување дека зголемувањето на побарувачката ќе се случи во време кога веројатно ќе има ограничувања на ресурсите на јавните услуги (Степни, 2018 година), заедно со предвидениот пад на бројот на неформални негуватели кои можат и сакаат да се грижат (Томпсон и Томпсон, 2005 година). Ова се должи на низа фактори - меѓу кои и претстојната криза на ресурси. Исходот е продлабочување на кризата во негата. Кризата веќе пристигна во многу европски земји и може да се идентификуваат три фактори што придонесуваат за тоа: прво, демографските трендови кои го истакнуваат растечкото старо население во Европа; второ, сериозна криза на ресурси и трето, загриженост за достапноста и квалитетот на негата. Да ги разгледаме подетално овие три фактори.

\section{Стареење на населението во Европа}

Населението во Европа очигледно е дека старее. Пропорцијата на населението од 65 години и постаро се предвидува да се зголеми од 18,9\% во 2015 година на 27,8\% во 2050 година, со пензионирањето на „бејби бум“ генерацијата (Евростат, 2018 година). Извештајот за стареењето на Европската комисија (2018) покажува дека вкупното население на ЕУ се предвидува да се зголеми од 511 милиони во 2016 година на 520 милиони во 2070 година. Меѓутоа, ако населението на возраст за пензија се зголемува, тогаш работоспособното население (оние помеѓу 16 и 64 години) се движи во спротивна насока и се предвидува да се намали од 333 милиони во 2016 година на 292 милиони во 2070 година. Стапката на сооднос на луѓето на возраст од 65 години и повеќе во однос на работоспособното население се предвидува значително да се зголеми од $29,6 \%$ во 2016 година на $51,2 \%$ во 2070 година.

Ако ги погледнеме оние над 80 години, честопати нарекувани „многу стари“, забележуваме слични трендови. Бројот на населението во Европа со 80 или повеќе години се предвидува драматично да се зголеми од 5,3\% во 2015 
година на 12,3\% до 2080 година. Бројот на многу старите луѓе се зголемува како дел од пензионираното население во Европа, и во 2020 година претставуваат скоро 22\% од сите постари луѓе (Европска комисија, 2018 година).

Овие проектирани статистички податоци ги одразуваат претпоставките за стапките на фертилитет, очекуваното траење на животот и миграциските текови и, што е важно, ќе имаат влијание врз ресурсите и фискалните трошоци поврзани со пензиите, здравствената заштита и долгорочната нега. Ова во основа значи дека фискалните трошоци за поддршка на порастот на стареечкото населението во Европа во голема мера ќе паѓаат на грбот на луѓето на работоспособна возраст - популација која полека се намалува. Ова веќе создава криза на ресурси, со помалку луѓе кои придонесуваат за трошоците за долгорочна нега преку даноци и придонеси за социјално осигурување.

\section{Претстојната криза на ресурси и загриженоста за достапноста на грижата}

Иако многу од постарите лица се грижат сами за себе, со напредувањето на возраста доаѓ до зголемена веројатност за влошување на здравјето, инвалидитет и проблеми со подвижноста. Всушност, се знае дека луѓето во просек трошат слична количина на здравствени ресурси во последната година од нивниот живот со онаа во севкупниот претходен дел од нивниот живот (Степни, 2018 година). Ова значи дека ќе бараме значителни дополнителни средства за здравствена и социјална грижа во многу блиска иднина, во време кога се предвидува намалување на бројот на неформални негуватели, особено жени. Порано постарите луѓе многу се потпираа на неформалната грижа во семејството, особено во јужна Европа и медитеранските земји. Но, ова започна да се менува поради повеќе жени на пазарот на трудот, распаѓањето на бракови и повисоките стапки на разводи, намалувањето на големината на семејството, поголемата географска мобилност, поделбата во заедницата и стареењето на негувателите (Антонен, Балдок и Сипила 2003; Вокер, 2005). Во срцето на кризата со ресурсите е сознанието дека жените повеќе не се во можност и не сакаат да прифатат исклучива одговорност за неформалната грижа.

Понатаму, кризата со ресурси во долгорочната нега доведе до зголемена побарувачка на државните услуги во време кога владите беа под притисок да ги ограничат социјалните издатоци со цел да се подобри нивната конкурентност на глобалните пазари. Економската глобализација ги преобликува националните економии во период кога растот на БДП забавува и во европските нации, како и на глобално ниво (Еврост, 2018 година). Ова ги принуди владите да ги ограничат растечките социјални издатоци со примена на построги критериуми за да се стане корисник на услугите, наплата на услугите и 
ограничување на пристапот само за најранливите лица или тие со висок ризик. Резултатот е рационализирање на државната поддршка и зголемување на непресретнатите потреби (Степни, 2018 година).

Кризата во финансирањето на долгорочната нега и загриженоста за достапноста значи дека една од несаканите последици на политиката е појавување на ,јаз во негата“. Само побогатите пензионери можат да купат и да ја набават негата што им е потребна преку проширениот пазар на приватна нега. Ова направи голем број постари луѓе да бидат зависни од државните придобивки чија реална вредност не е во чекор со инфлацијата (Евростат, 2018 година). Се проценува дека значителен број луѓе над 65 години живеат во или на маргините на сиромаштија. Во 2014 година над 16 милиони постари луѓе (на возраст над 65 години) беа изложени на ризик од сиромаштија и 18\% беа категоризирани како сиромашни во од државата, од нивните семејства или од нега од доброволниот или 'третиот сектор' за да се исполнат нивните секојдневни потреби. Оваа зависност е социјално конструирана и е поврзана со класата, културата, етничката припадност и полот.

\section{Социјалната конструкција на зависност (издржуваност) во староста}

Социјалниот статус по пензионирањето се најде во голем број студии кои се во корелација со статусот на вработување пред пензионирањето (Вокер, 2005 година; Акино и сор., 1996 година). Ова значи дека оние лица со повисоки примања имаат поголема веројатност да акумулираат заштеди, имот и работни пензии. Како и ефектите од класата, расата и културата, жените поминуваат полошо во сите професионални категории, едноставно затоа што имаат просечна помала

Слика 1: Стапки на учество на пазарот на трудот кај постарите луѓе

\begin{tabular}{|l|c|c|c|}
\hline & Сите \% & Жени \% & Мажи \% \\
\hline Возраст од 65 години и повеќе & & & \\
\hline Обединетото Кралство & 5.1 & 3.5 & 7.4 \\
\hline Германија & 2.7 & 1.6 & 4.4 \\
\hline САД & 12.2 & 8.6 & 17.1 \\
\hline
\end{tabular}

Извор: Анйонен, Балgок и Сийила 2003 іояина

ЕУ (Антчак и Заиди, 2016 година). Додека поголемиот дел од постарите луѓе сакаат да ја задржат својата независност, тие се повеќе стануваат зависни заработка. Низ цела Европа од жените се бара порано да се пензионираат, а сразмерно помалку жени отколку мажи работат по достигнувањето на возраста 
за пензија (Антонен, Балдок и Сипила 2003 година). Слика 1 го илустрира ова за Обединетото Кралство, Германија и САД.

Постојат низа причини за променлива стапка на учество на пазарот на трудот кај постарите луѓе. Според Вокер (2005 година), најосновната причина е што социјалните и економските политики имаат тенденција да дејствуваат заедно во целокупното управување со економијата. Ова претставува фиксна возраст за пензионирање, за да се олеснат постарите работници од пазарот на трудот. Претпоставката дека постарите работници се помалку продуктивни и затоа се распределуваат е многу оспорена и има многу анегдотски докази што го сугерираат спротивното - универзитетските професори се само еден пример! Државата понекогаш го стимулираше намалувањето на постарите работници со воведување на шеми за предвремено пензионирање и ограничување на можностите за преквалификација на помладите работници. Сепак, притисокот за работа останува, бидејќи пензиите во Обединетото Кралство не држеа чекор со инфлацијата, додека скромните издатоци за социјално осигурување го намалија социјалниот статус на постарите луѓе.

Во понатамошно продолжување на дебатата, Вокер (2005 година) ги потенцира квалитативните аспекти на социјалната грижа, како во домовите за нега, така и во заедницата, кои имаат тенденција да ја зајакнат зависноста и да ја поттикнат пасивноста, без оглед на здравјето. Сево ова се сведува на социјалната конструкција на зависност во староста, резултат на социјалната и економската политика кои што работат во тандем. Во продолжение ќе разгледаме како изградбата на зависност во староста стана централен елемент на политиката за грижа во заедницата во Обединетото Кралство.

\section{Социјалната конструкција на политиката за грижа во заедницата во Обединетото Кралство}

Здравјето и социјалната заштита на стари лица традиционално се под влијание на концептите за затегнување на трошоците за заштита, наместо превенција и здраво стареење, што е наследство од социјалната политика од 19-тиот век (Пејн, 1995; Грел, Канингем и Јуте, 2017 година). Социјалните нееднаквости во здравството не се намалија во текот на изминатите 40 години, а стапките на морталитет и морбидитет низ Европа сѐ уште откриваат поврзаност со социјалната класа (Бакер и Мекенбах, 2003 година). Во Обединетото Кралство до крајот на 1980-тите, по објавувањето на , Грижа за луї́е̄̄o “ (ДоХ, 1989 година), владата на Маргарет Тачер користеше демографски трендови и предвидувања на трошоците за да потврди дека седеле на ,временска бомба со ресурси“. Грижата во заедницата беше предложена како ефикасен начин за намалување на трошоците и подобрување на сос- 
тојбите. Во услугите за возрасни, ова значеше развој на мешана економија на обезбедување, вклучително и поделба на државните услуги, централизирана контрола и зголемена маркетизација со зголемена улога за приватниот и доброволниот или „третиот сектор“. Според многу влијателни писатели, овој пакет на политики неизбежно ќе доведе до резидуализација на јавните услуги (Минс, Ричардс и Смит, 2008 година; Вокер, 2005 година; Пејн, 1995 година).

Основниот проблем со реформите на грижата во заедницата во Обединетото Кралство беше што тие беа спроведени врз основа на слаби докази и следеа долга традиција на неуспешна политика маскирана со политичка реторика. За многумина, политиката за грижа во заедницата имаше својствени ограничувања што произлегоа од значителен недостаток во однос на „заедницата“ и „грижата“. „Идеалот на заедницата“" е информиран од две спротивставени традиции. Првиот, поконзервативно верување во заедницата како взаемна помош и волонтерство што промовира индивидуална одговорност. Второто, порадикално верување дека заедницата може да поттикне социјална интеграција и да стане место за колективни одговори на неволји и лишеност. Тоа беше првата традиција што ја информираше политиката во Обединетото Кралство.

Иако не беше изненадувачки, реформите во грижата за заедницата содржеа фундаментална противречност помеѓу развојот на поодговорни и зајакнувачки услуги од една страна, нудејќи им на корисниците поголем избор на услуги, и од друга страна постигнување подобра вредност за потрошените пари, преку поголема употреба на пазарот за да ги задржат трошоците (Томпсон и Томпсон, 2005 година; Вистоу, 1995 година). За многу постари луѓе, како што заклучи неодамнешното шведско истражување, нивната улога како потрошувачи на новиот пазар на грижа, беше збунувачката и проблематична (Вамстад, 2016 година). Ова го отсликува искуството и на постарите луѓе во Обединетото Кралство (Глендининг, 2009 година).

Како што се зајакнуваше мешаната економија на грижа, се појавуваше несовпаѓање помеѓу реториката на политиката и реалноста во практиката: услугите во заедницата беа пазарно раководени наместо водени од потребите; ограничувањето на трошоците доби поголем приоритет од зајакнувањето на корисниците; институционалниот стил на грижа и контрола продолжи да функционира иако маскирано, медицинските професионалци ја задржаа својата доминантна улога во мултидисциплинарни тимови и покрај критиките и разговорите за „берлинскиот мид“ помеѓу здравствените и социјалните служби (Глазби, 2003 година). Таквата тензија помеѓу здравствената и социјалната грижа ќе биде разгледана во следниот дел. 


\section{Поместувачката граница помеѓу здравствената и социјалната грижа}

Во времето кога се формулираа реформите за грижата во заедницата во Обединетото Кралство, здравствената заштита претрпе значителна промена во акцентот кон поисплатлива, куративна и пазарно ориентирана услуга. Во овој период Вистоу (1995) аргументираше дека движечката сила во рамките на британската Национална здравствена служба (NHS) беше воведување индекс на ефикасност кој го мери одговорот на потребите на пациентите преку зголемениот третман, пропусната моќ и целите на листата на чекање. Спротивно на тоа, реформите на грижата во заедницата беа засновани, барем во теорија, врз ,холистичката проценка на потребата, индивидуалните пакети за грижа и зајакнувањето на корисниците на услуги да направат информиран избор“ (Вистоу, 1995, стр. 234).

Реформите во грижата во заедницата беа спроведени во време кога се менуваше обезбедувањето престој во болницата па така, помеѓу 1989 и 1994 година, бројот на подолг престој за постари лица беше намален за 23\% (Вистоу, 1995). Неодамнешна анализа сугерира дека овој тренд продолжил „и покрај зголемувањето на приемите, бројот на општ долг престој и акутни легла во болниците во NHS паднал од 126.976 во 2006 година на 106.374 во 2013 година“ (Смит и сор., 2014, стр. 3). Понатаму, ако ги погледнеме приемите во болница по возрасна група, откриваме дека имало „25\% зголемување на приемите кај постари лица на возраст од 65-84 години и драматично зголемување од 43\% кај оние на возраст од 85 и повеќе години“(Смит и сор., 2014 година, стр. 4). Ова разбирливо создаде тензии помеѓу здравствената и социјалната заштита во време на ограничени буџети и доведе до нови проблеми, вклучително и таканаречено „блокирање на кревети“ и предвремено отпуштање на постари луѓе (Форд и Степни, 2003 година). Ке се навратиме на ова подоцна.

Општата слика што произлегува од истражувачката литература е дека, и покрај овие проблеми, постигнат е напредок кон интеграција на здравствената и социјалната грижа и развој на подобра соработка помеѓу персоналот. Најзабележителен напредок е во развојот на креативни пакети за грижа за постари лица кои бараат интензивна поддршка од заедницата. Сепак, постојат докази за зголемување на притисокот врз ресурсите, заострување на критериумите за подобност, повеќе наплата и одредено ,рационализирање“, особено за оние со помали потреби за нега (Мортимер и Грин, 2015 година). Извештаите од постарите луѓе и нивните негуватели сугерираат дека иако некои аспекти од нивната грижа биле позитивни, тие допрва треба да доживеат значителни подобрувања и дека зајакнувањето сѐ уште останува повеќе реторика отколку реалност (Темесел-Хубер, Хабард и Мунро, 2007 година; Вокер, 2005 година). 
Основниот проблем што ја поткопува подобрата соработка помеѓу здравството и социјалната заштита е тоа што иако случајот за интеграција беше прифатен, тој беше загрозен од сериозното ограничување на буџетот. Без потребните ресурси, јавните служби се бореа да се справат со демографските промени и растечката побарувачка, додека дискриминацијата и исклучувањето по основ на возраст (,старизмот“) продолжи во она што беше наречено „возраст на напредната маргиналност“ (Ваквант, 2007 година). Овие проблеми постоеја ширум Европа, па така социјалната политика на Обединетото Кралство ќе ја разгледаме во поширок европски контекст и ќе ги испитаме конкурентните модели на социјална благосостојба во Европа.

\section{Четири европски социјални модели}

„Предизвик е да се замислат и спроведат социјални реформи насочени кон поголема економска флексибилност и подобра социјална заштита “(Андре Сапир, 2013, стр. 5)

Иако постарите луѓе се соочуваат со голем број на заеднички проблеми, како што се дискриминацијата, зависност од поддршка од други, исклучувањето и ограничениот пристап и квалитет на грижата, одговорот на европските влади беше обележан со значителна разновидност (Сапир, 2013 година). Овие разлики се историски и може да се согледаат во различните системи на со- цијална заштита. Антологиската работа на Еспинг-Андерсен (1990) има исклучително влијание во идентификувањето на три типологии на социјална држава, кои можат да се анализираат во смисла на комодификација и раслојување - степенот до кој државната благосостојба нуди заштита од ефектите на комодификацијата на пазарот и ги намалува исходите засновани на класата.

Трите оригинални типологии ја воспоставија рамката за многу последователни компаративни истражувања во социјалната политика. Прво, постојат либерални социјални режими, кои се претставени од Обединетото Кралство и САД, кои имаат многу скромни нивоа на социјални бенифиции (пензии, инвалидитет, надоместоци за болести), но пообемни ,социјални сигурносни мрежи“ за социјална заштита заснована на проверка и целно насочена поддршка за вработените кои се сиромашни. Втори се корпоративните социјални држави, кои се олицетворени од Германија, кои имаат повеќе дарежливи бенефиции од социјалното осигурување, финансирани од придонесите од заработката. Недостаток е што овие ги одржуваат нееднаквостите во приходите, фаворизираат мажи пред жени и ги „казнуваат“" оние надвор од пазарот на трудот. Трети се социјалдемократските социјални држави во нордиските земји, кои имаат обемни социјални услуги, кои се финансирани со високи нивоа на оданочување и придонеси за социјално осигурување. Во Шведска и Финска, се смета дека социјалната држава придонесува за со- 


\section{Слика 2: Четири европски социјални модели}

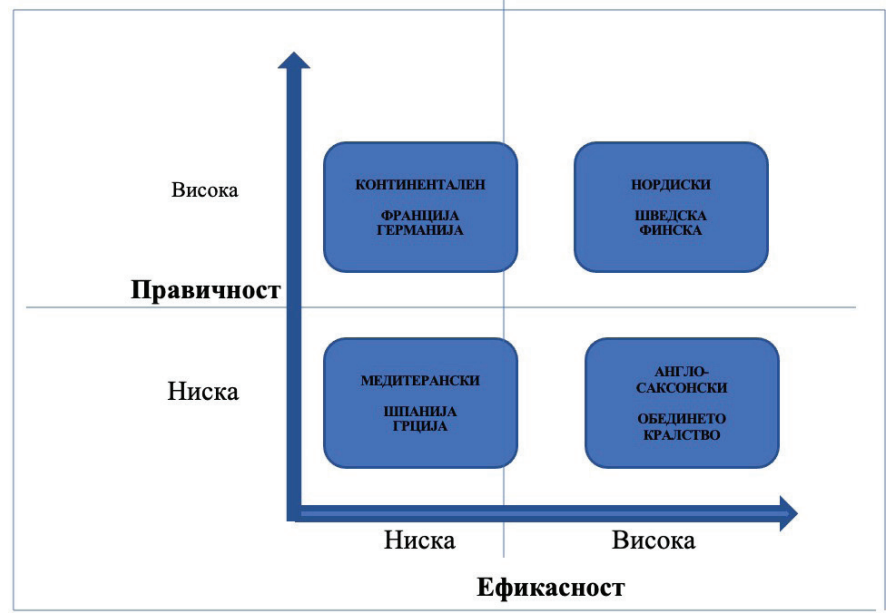

Извор: Сйейни, 2018 іоомина

цијална солидарност, така што прераспределбата и универзализмот добиваат широка поддршка од јавноста.

Трите типологии се преформулирани од страна на Сапир (2013 година) со цел да вклучи четврти модел базиран на медитеранските земји (види слика 2), споредувајќи ги социјалните држави врз основа на правичност и ефикасност.

Четирите режими реагираа прилично поинаку на кризата во долгорочната нега и предизвикот да им се понуди на постарите луѓе поголем избор и поддршка, како и на ограничувањето на социјалните издатоци преку придржување кон диктатот на глобалниот пазар.

Либералниот англосаксонски модел во Обединетото Кралство се залага за социјална дерегулација, маркетизација и приватизација. Ова ги прошири нееднаквостите помеѓу богатите постари луѓе и оние пензионери зависни од државните бенефиции, и сега многумина се во опасност од сиромаштија. Имаше раст во ниско платените социјални услуги во новиот пазар на социјална грижа, вработувајќи главно жени и нови мигранти.

Во континенталните социјални држави како Германија, невработеноста остана прилично висока, но справувањето со социјалната исклученост наспроти сиромаштијата останува приоритет. Услугите за социјална грижа се претежно во „третиот сектор“, но тој не вработува голем број луѓе. Според Сапир (2013) иако континенталниот модел е правичен, сепак се потребни реформи за подобрување на ефикасноста и справување со нееднаквостите.

Во нордиските земји, „нордискиот модел на благосостојба“, и покрај одредено намалување, ја задржува силната посветеност на еднаквоста и социјалната солидарност (Кананен, 2014). Нордиските земји имаат најви- 
соки стапки на социјална прераспределба и најниско ниво на сиромаштија во Европа (Сапир, 2013). Постарите луѓе обично живеат во станови кои се опслужувани со флексибилна поддршка и не очекуваат нивните деца да се грижат за нив. Како и да е, јавната благосостојба е скапа поради големата јавна администрација, во која работат главно жени, и оваа сегментација на женското вработување е признаена како проблем.

Во медитеранските земји заштитата на вработувањето и поддршката за постарите лица се приоритет. Семејството игра активна улога во благосостојбата на постарите луѓе на кои им е потребна грижа (Хантраис, 2004 година), вршејќки притисок врз жените да обезбедат неформална грижа. Медитеранскиот модел обично има ниски стапки на прераспределба и голем број на постари луѓе изложени на ризик од сиромаштија. Ова значи дека се гледа како најмалку правичен и ефикасен од четирите модели и има потреба од реформа (Сапир, 2013 година).

Следниот краток пример од праксата ги илустрира проблемите со кои се соочуваат постарите луѓе на кои им е потребна грижа и како локацијата во Европа влијае на исходите.

\section{Пример од пракса}

Аїнейа е изнемошӣена йосӣара жена која чека gа бияе оййуийена оg іраяскайа болница ойкако се ойорави og йневмонија. Проценкайа на нејзини-

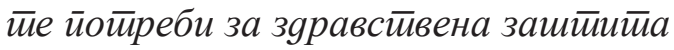

и ірижа ойкри дека има анйина и е на іраница за gа остиане независна / за која е йойребна резияенцицјална неїа. Таa има еgна ќерка која живее во блискиой ірая и рабойи со йолно рабойно време. Дояека Аїнейа е йоgвижна и сака gа ја

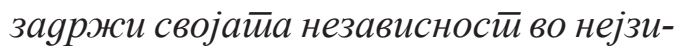

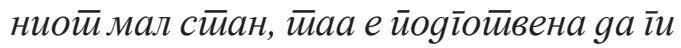
разйлеgа различнийе ойц̧ии.

Врз основа на различните видови на грижа за постари лица кои обично можат да бидат достапни на различни европски локалитети, ги испитуваме различните опции за долгорочна нега за Агнета. Притоа треба да се има предвид дека има многу национални и регионални варијации, па се препорачува претпазливост при дискутирање на опциите и давање препораки. Прашањето што треба да се постави е - кој европски социјален модел обезбедува најкорисна рамка за политика за обезбедување ефективна долгорочна нега за ранливи граѓани како Агнета?

Ако Агнета живее во англосаксонскиот или континенталниот модел, ќе и се понуди пакет грижа за да се издржува дома, со таа разлика тоа што во Обединетото Кралство ова најверојатно ќе биде од приватен добавувач, додека во Германија ќе беше од агенција од „трет сектор“. Приватизацијата и маркетингот на грижата се развиваат во Германија, но со побавна стапка од Обединетото Кралство. И во двете земји грижата ќе се следи и ќе се проценува ефективноста. Процената во Обединетото Кралство, за да се донесе одлука за долгорочна нега (институционална 
или домашна нега) ќе биде заснована врз проценка на ризикот, цената како и желбите на Агнета, но со надолен притисок да се избере најевтината опција. Во Германија би имало повеќе избор, но тоа се однесува на статусот на социјалното осигурување на Агнета и здравството. Керката на Агнета би била консултирана, особено ако придонесе со неформална грижа.

Во медитеранскиот модел, типичен за Јужна Европа, Агнета ќе зависи повеќе од неформалната грижа бидејќи и домашната и институционалната заштита се неразвиени во споредба со нордиските земји и континентална Европа. Бројот на легла за долгорочна нега започна да се зголемува во последниве години, бидејќки повеќе жени, кои го работат поголемиот дел од негата, влегоа на пазарот на трудот (Спасова $u$ cop., 2018 година) и трошоците за социјална грижа како процент од БДП сега се зголемуваат (Комисија на ЕУ, 2018 година). Оттука, керката на Агнета и можеби другите негуватели ќе имаат главен збор во секоја одлука за долгорочна нега. Поддршката за домашна нега е пожелна, но може да биде тешко пристапна заради вишокот на побарувачка над понудата, додека институционалното сместување ќе се смета како последно средство.

Во нордиските земји домашната нега е исклучително добро развиена, добро регулирана и поддржана од државни агенции. Пензиите се исто така највисоки во Европа, така што Агнета ќе има можности да купи и дополни- телна поддршка доколку има потреба. Здравствената заштита е исто така тесно интегрирана со социјалната заштита, така што Агнета треба да добие високо квалитетен мониторинг на нејзината состојба на срцето и интегрирана социјална поддршка. Во последниве години постои одредено намалување на јавните услуги заедно со ограничената маркетизација (Антонен и Хаикио, 2011 година), но сепак, долгорочната нега со висок квалитет е норма. Веројатно е дека Агнета живее во стан кој е поврзан со мрежа на интегрирани услуги. Ова значи дека ако нејзиното ниво на зависност се зголеми со текот на времето, таа ќе може да има пристап до дополнителни услуги и поддршка. Во нордискиот модел нема да има никакво очекување дека нејзината ќерка ќе понуди неформална нега.

По нашето испитување на различните европски социјални модели, кои ги потенцираа предностите на нордискиот пристап за обезбедување ефективна долгорочна нега на изнемоштени постари граѓани како Агнета, сега се навраќаме на ситуацијата во Обединетото Кралство. Тука се издвојуваат три трендови: намалување на болничките кревети, зголемен акцент на ризик и тешкотиите при поместувањерто на границата помеѓу здравствената и социјалната заштита. Одговорите на овие трендови сѐ повеќе почнаа да ги кројат агендите за професионалната социјална работа. 


\section{Преобликување на практиката за социјална работа}

Со оглед на вградените тензии во рамките на политиката за грижа во заедницата во Обединетото Кралство, превенцијата се гледаше како цела услуга достојна за пофалба, но која би се случила „само во добар ден“, нешто што „треба да се направи утре, а не денес“ (Степни, 2014 година). Неизненадувачки, фокусот на социјалната вклученост и благосостојба, што беше содржан во „изјавите за мисија на политиките“ и беше признаен како важен, брзо стана подреден на потрошувачката на пазарот и настојувањето да се зголеми ефикасноста и да се намалат трошоците (Томпсон и Томпсон, 2005 година). Слични трендови последователно се појавија, иако во помал обем, во нордиските социјални држави Финска и Шведска (Антонен и Хаикио, 2011 година; Вамстад, 2016 година).

Еден главен наратив кој сѐ повеќе доминира во професионалните проблеми и приоритети, како во државните услуги, така и во услигите испорачани од доброволните или агенциите од „третиот сектор“, се однесува на концептот на ризик. Дебатите за ризик сега навлегуваат во процесите на проценка и се наметаа врз традиционалната загриженост за нега и поддршка (Степни, 2018 година). Во Обединетото Кралство, процената, следењето и управувањето со ризикот стана основна задача, особено во законски пропишаните социјални услуги
- тренд засилен со законодавството и директивите на политиките. Иако овој акцент е разбирлив, тој е во спротивност со оригиналната визија за грижа во заедницата како услуга за зајакнување што промовира независност и избор. Неодамнешните реформи во социјалната грижа кои беа воведени во Обединетото Кралство, беа засновани врз политики на персонализација, самонасочена поддршка и индивидуални финансиски буџети (Лимбери, 2012 година). Сепак, ова е конзумеристички пристап кој не се поврзува лесно со секојдневното искуство на ранливите постари луѓе, кои сѐ повеќе живеат во сенка на пазарот и кои би биле подобро услужени со поголем акцент на превенција, зајакнување и права (Степни, 2014 година).

Луѓето од праксата сѐ повеќе се обидуваат да развијат посеопфатни и интегрирани пристапи кон потребата на клиентот, пристапи кои го препознаваат негативното влијание на дискриминацијата заснована на возраст, зависноста и неповолната социјална положба. Следствено, растечкиот акцент врз ризикот во социјалните услуги е придружен со фокусот врз насочување кон зајакнување што го одразува зголемениот интерес за менталната благосостојба на постарите луѓе, вклучувајќи ја и духовноста - „како секој од нас бара значење, цел и насока во својот живот“" (Томпсон, 2019 година, стр. 37). Благосостојбата е холистички сеопфатен термин што се однесува на квалитетот на современиот живот и потребата да се 
бара поголема среќа, задоволство и значење, за да се пресретнат проблемите на изолација, исклучување и осаменост во староста (Томпсон, 2019 година).

Промоцијата на благосостојбата стана една од примарните цели на модернизираните социјални услуги, и со воведување на заедничка цел се создадоа услови за нови партнерства меѓу агенциите од здравството, социјалната грижа, и доброволните или агенциите од „третиот сектор“. Потрагата по нови партнерства, особено меѓу здравствените и социјалните услуги, ја потенцира потребата за подобрена соработка помеѓу персоналот кој директно работи со корисниците.

\section{Колаборативно работење}

Колаборативната работа е пристап информиран од кластер на концепти, како што се „меѓу-професионално“, „соработка“, „,тимска работа“ и ,партнерство“, кои имаат тенденција да се користат на различни начини во зависност од организацискиот и професионалниот контекст (Леатард, 2011 година; Степни, 2018 година). Наједноставно, колаборативното работење означува дека персоналот од различно професионално и академско потекло формира работен однос или партнерство со цел давање подобрени услуги. Сепак, како што беше откриено со едно неодамнешно истражување спроведено во тринаесет европски земји, точната природа на партнерството веројатно ќе се оспори, додека целосно интегрираните „здружени“ „засновани на личноста“" услуги досега се покажаа неостварливи (Ступ и сор., 2020 година) .

Во срцето на дебатата за колаборативна работа постои одредено чувство за професионална амбивалентност. Од една страна, постојат многи залагања за соработката, како во политиката, така и во стручната литература. Од друга страна, постојат безброј примери на проблеми и тензии кои се јавуваат секогаш кога овие идеи ќе се применат во пракса (Карича $u$ сор., 2004 година). Според многу аналитичари, (види на пример Пејн, 1995 година; Лимбери, 1998 година; Литхард, 2011 година; Степни, 2014 година) соработката има значителен потенцијал за правење позитивна разлика и подобрување на услугите за постарите луѓе, но и покрај тоа, таа продолжува да биде оптоварена со тешкотии.

Иако придобивките од заедничката работа ретко се оспорувани, нејзината примена во социјалната работа во голема мера беше во доменот на заштита на децата и менталното здравје, отколку кај услугите за постари луѓе. Ова е голема штета бидејќи заедничката работа има потенцијал за развој на стратегии за превенција кои можат да им овозможат на постарите луѓе да живеат самостојно и безбедно и подолго во заедницата. Во контекст на сегашната криза Ковид-19, потребата за соработка не може да биде поголема - став кој е во согласност и со неодамнешната изјава на Ханс Клуж од Светската здравстве- 
на организација (С3О) „Поддршката и заштитата на постарите луѓе кои живеат сами во заедницата е работа на сите“, (Клуж, 2020 година). Потребата за соработка повторно беше нагласена во изданијата на вестите на Евройскойо јавно здравје (ЕПХ) (Лејланд и Клуге, 2020 година) на СЗО во август 2020 година. Ова е нешто што се појавува во трите современи прашања од интерес што сега ќе ги испитаме.

\section{Три современи прашања од интерес}

\section{(I) Исииушйање оg болница кај иоссйари лица}

Кога првпат извршив истражување за ова прашање, открив дека иако проблемот со „одложено отпуштање“ или т.н. „блокирање на креветот“ секако постоеше, еден потенцијален и посериозен проблем беше доста чест и најчесто занемарен. Тука пред се мислам на проблемот на предвременото отпуштање (Форд и Степни, 2003 година). Истражувачката литература тогаш, како и сега, има тенденција да го потенцира првиот проблем (Глазби, 2003 година; Чалис и сор ., 2013 година), поради доцнење во поставувањето на домашна нега, наоѓање на соодветен дом за грижа или спорови за финансирање, но не го пријавува проблемот на постари луѓе кои понекогаш биле предвремено итно отпуштени од болница за да ослободат акутен или кревет за долг престој. Дополнително, моите истражувачки наоди објавени во
Европската ревија за социјална работа ретко се цитирани. Оттука, проблемот со предвременото отпуштање на постари лица останува во голема мера непризнат.

Актуелната криза „Ковид-19““повторно го изнесе проблемот на површина, особено предвременото пренесување на постарите луѓе од болница во домови за згрижување без претходно да бидат тестирани за вирусот. Исходот од тоа - големиот број смртни случаи се гледа како неуспех на политиката, која не е ограничена само на Обединетото Кралство. Проблемот со голем број смртни случаи во домови за нега се појави во други европски земји, особено во Шпанија и Белгија и покрај тоа што тестирањето за корона вирусот е пообемно, а во помала мера и во Шведска и Франција. Шведска е исклучок во споредба со другите европски земји поради отфрлањето на политиката на карантин, но сепак не беше во можност да спречи голем број смртни случаи во домовите за нега (Слика 3 ).

Бројот на жители кои умираат во домови за згрижување во Обединетото Кралство, како процент од сите жители на домови за згрижување, беше приближно двојно поголем од оној во Франција и Шведска, и 13 пати поголем отколку во Германија. Ова значеше дека околу 3.500 постари луѓе починаа во домови за згрижување во Германија во споредба со 16.000 во Обединетото Кралство, и покрај тоа што Германија имаше далеку поголема популација во домовите за згрижување. Причината може да се припише на широкиот гер- 
Слика 3: Смртни случаи припишани на Ковид-19, изразени како процент од сите жители на домови за нега, во избрани европски земји

\begin{tabular}{|l|l|l|l|l|l|l|}
\hline & $1,00 \%$ & $2,00 \%$ & $3,00 \%$ & $4,00 \%$ & $5,00 \%$ & $6,00 \%$ \\
\hline Шпанија 6.1 & & & & & & \\
\hline Обединетото Кралство 5.3 & & & & & & \\
\hline Белгија 4.9 & & & & & & \\
\hline Ирска 3.2 & & & & & & \\
\hline Италија 3.1 & & & & & & \\
\hline Шведска 2.8 & & & & & & \\
\hline Франција 2.4 & & & & & & \\
\hline Данска 0,5 & & & & & & \\
\hline Словенија 0,5 & & & & & & \\
\hline Германија 0,4 & & & & & & \\
\hline Норвешка 0,4 & & & & & \\
\hline
\end{tabular}

Извор: Буй, 2020 іодина, іррафик на Гарgијан, 29 јуни 2020 іоояна,

Лондонска школа за економија

мански систем за тестирање и трагање и 14-дневен карантин за секој што излегува од болница.

Откако ќе се смири пандемијата на короната, ќе дојде време за повторна проценка на протоколите за отпуштање од болница насекаде, особено за изнемоштените постари луѓе како Агнета на границата за домашна / резиденцијална нега. Едно време секоја поголема болница имаше тим за социјална работа на лице место, кој преземаше одговорност за планирање на отпуштањата. Денес тоа веќе не е случај, а аранжманите за отпуштање се рационализирани и преземени од различен медицински и административен персонал, понекогаш во брзање. Потребен е заеднички сет на стандарди и индикатори на ЕУ за да се обезбеди квалитет и со тоа да се овозможи постарите лица да добијат помош и поддршка што им е потребна кога ќе заминат од болница.

\section{(ii) Управување со ризикот и дилемите во пракса}

Бидејќки концептот на ризик се провлекува во политиките за здравствена и социјална грижа како и во праксата, проблемот на градење ефективни системи и процедури за управување со ризици бара итно внимание. Постарите луѓе најчесто се соочени со најповеќе проблеми донесени за нивната долгорочна нега по проценката на ризикот. Најновите истражувања (Тејлор, 2005 година) открија фундаментален проблем, затоа што процедурите за управување со ризици на агенцијата не секогаш одговараат на концептуалната рамка на вклучените професионалци. 
Понатаму, парадигмите за ризик што ги користат професионалците согласно прирачниците за управување со грижата содржат вградени противречности и тензии. Тејлор (2005 година) откри дека парадигмата за контрола на ресурсите и ефикасноста или капацитетните приоритетите се косат со пресретнувањето на потребите и решавањето на мерките за заштита. Ова ја направи професионалната задача за проценка на ризикот попроблематична.

Друго поврзано прашање е дека иако барањето да се минимизираат опасностите е очигледно вредна цел, прашањето - што претставува дозволена опасност останува нерешено и е прашање на професионална проценка. Кога постара личност е оценета за домашна нега, може да се идентификуваат разни опасности - на пример, правилни лекови што треба да се земаат, сообраќај надвор од нејзиниот стан ако лицето почине, оган од гас во нејзиниот стан, остар прибор во кујната, чекорот за доѓање до бања или туш и така натаму. Сите овие опасности од ниско ниво претставуваат ризик што мора да се препознае доколку постарата личност сака да живее самостојно дома. Професионалецот, се разбира, може да помогне да се минимизираат со прифаќање на индивидуален пристап (Ступ $u$ сор., 2020 година) и да дискутираат за ризиците со постарата личност, и можеби да им предложат да носат безбедносен аларм. Посетите од персоналот за домашна нега можат да помогнат со следење и поддршка каде што е потребно за да се осигура дека ризикот е управуван на интегриран и персонализиран начин. Така, дилемите за управување со ризици можат да бидат ограничени со усвојување на интегриран пристап заснован на индивидуалните потреби (Ступ $u$ сор., 2020 година).

\section{(iii) Растечкиот тренд на чинење на долгорочната нега}

Еден од најсериозните проблеми идентификувани со истражувањата и навистина честопати самата постара личност се однесува за достапноста и цената на долгорочната нега. Ова се сметаше за важно прашање уште во 80-тите години на почетокот на грижата во заедницата кога деинституционализацијата добиваше сила (Пејн, 1995 година; Вистоу, 1995 година). Сега се појавува зачестено во новите публикации на ЕУ кои се однесуваат на финансиската одржливост на долгорочната нега (Спасова, и сор., 2018 година; Европската комисија, 2018 година). Проблемот е во тоа што, со оглед на демографските трендови и предвидените трошоци, досега не е најдено одржливо и политички прифатливо решение. Тоа е класичен проблем со политиките, полни со бројни политички потешкотии кои ги убедија политичарите да го заборават проблемот и да остават да го реши следната влада. Plus ça change, plus c'est la même chose.

Соодветното и одржливо финансирање на долгорочна нега се смета можеби како еден од најголемите предизвици 
со кои се соочува секоја европска влада денес. Предизвик е да се задоволи идната побарувачка, имајќи предвид дека истражувањата сугерираат дека побарувачката започна да се забрзува и веројатно ќе достигне врв околу 2040 година (Карлсон и сор., 2006 година). Веројатно е дека најзначајната побарувачка ќе биде за домашна нега дополнета со неформална нега и поддржана од услуги на ниско ниво. Побарувачката за домашна нега се предвидува да порасне од 2,2 милиони места во 2006 година на 3 милиони до 2050 година. Ова значи дека трошоците за домашна нега соодветно ќе се зголемат од 11 милијарди фунти во 2006 година на околу 15 милијарди фунти во 2040 година (по цени од 2001 година) ( Карлсон $u$ cop., 2006 година). Овие бројки не ги вклучуваат предвидените трошоци за резиденцијална нега и ги земаат предвид регионалните варијации. Последователно, мора да се изнајдат решенија ширум ЕУ за ескалираниот предизвик за трошоците и за креаторите на политиките да ги усвојат препораките во влијателните извештаи на ЕУ кои повикуваат на ,поефикасни и економични мерки ... посилен акцент на рехабилитација и социјални инвестиции, вклучувајќ стратегии за превенција '(Спасова и сор., 2018 година, стр. 4).

\section{Заклучоци}

Во трудот е опфатен материјал за тековната криза во долгорочната нега кај постари лица со критичко набљуду- вање на пазарно раководениот пристап во Обединетото Кралство заедно со упатувањето на ситуацијата во другите европски земји. Дебатата за политиката беше информирана со упатување на различни европски социјални модели, истакнувајќи ја силата на нордискиот модел, и извештајот на ЕУ за долгорочна нега (Спасова, $u$ сор., 2018 година). Политиката за долгорочна нега за постари лица беше поврзана со преобликување на професионалната пракса, потребата за соработка помеѓу здравството и социјалната заштита, и илустрирана со упатување на голем број тековни проблеми - вклучително и отпуштањата од болница, управувањето со ризик и проблемите на достапност, одржливост и цена. Проблемот со трошоците е оној што лидерите на ЕУ го сметаат за најитен, но нерешлив.

Во моментов, трошоците во рамките на ЕУ за долгорочна нега во домот се најголеми во нордиските земји и Холандија (Европска комисија, 2018 година). Сепак, треба да се запомни дека само релативно мал дел од здравствените трошоци се посветени на долгорочна нега, најголемиот дел секако е на акутна нега на пациентите. Ако грижата во заедницата ги задоволи потребите на стареечкото населението во Европа, тогаш трошењето треба повторно да се избалансира од акутна кон долгорочна нега, особено домашна нега. Цената, достапноста и квалитетот на долгорочната нега и понатаму се важни прашања и иако политиката ја препознава важноста на неформалната грижа, а во 
одредена мера се потпира на домашна работа на жените, треба да се направи многу повеќе за поддршка на негувателите. Поддршката на негувателите претствува поддрпка и за постарата личност (Ван Ено и сор., 2016 година) и ова е само едно од многуте прашања што бараат акција од цела Европа.

Постојат голем број позитивни чекори што може да се преземат за да се спротивставиме на инерцијата на политиката, да се подобри постојната грижа за постарите лица и иднината на долгорочна нега да се направи поодржлива. Клучот може да биде во двојните концепти на спречување и рехабилитација (Степни, 2014 година). Високата вредност на ниското ниво на поддршка традиционално се потценува. Меѓутоа, истражувањата покажуваат дека постарите лица ги вреднуваат услугите кои ги задоволуваат нивните т.н. потреби од „ниско - ниво“ (Кларк, Дајер и Хорвуд,
1998 година). Врз основа на ова дадени се и следните препораки за праксата

\section{Препораки за праксата}

Постои силен случај за развој на пообемни превентивни услуги засновани на грижата во заедницата, и инвестиции во рехабилитација, интегрирано обезбедување и домашна нега која е индивидуално заснована, особено за постарите лица кои ја напуштаат болницата. Постојат добри истражувачки докази што го поддржуваат ова (Степни, 2014 година; Ван Еноу, и сор., 2016 година; Спасова и сор., 2018 год). Ова сигурно ќе има одредена дополнителна цена, но тоа може да се покаже како мудра инвестиција што ќе ја зајакне одржливоста, ќе ја промовира интеграцијата на услугите и ќе донесе многу долгорочни придобивки.

\section{Користена литература}

Antczak, R. and Zaidi, A. (2016). Risk of Poverty among Older People in EU Countries. CESifo DICE Report, ISSN 1613-6373, ifo Institut - Leibniz-Institut für Wirtschaftsforschung an der Universität München, München, 14 (1), pp. 37-46.

Anttonen, A., J Baldock, J. and Sipilä, J. (Eds) (2003). The Young, the Old, and the State: Social care systems in five industrial nations. Cheltenham, UK: Edward Elgar.

Antonnen, A. and Häikiö, L. (2011). Care 'going market': Finnish elderly-care policies in transition, Nordic Journal of Social Research, Special Issue 2, pp. 70-90.

Aquino, J., Russell, D., Cutrona, C. and Altmaier, E. (1996). Employment status, social support and life satisfaction among the elderly. Journal of Counselling Psychology, 43(4), pp. 480-489.

Bakker, M. and Mackenbach, J. (Eds) (2003). Reducing Inequalities in Health: A European Perspective. London: Routledge.

Barnett, K., Mercer, SW., Norbury, M., Watt, G., Wyke, S. and Guthrie, B. (2012). Research paper. "Epidemiology of multimorbidity and implications for health care, research, and 
medical education: a cross-sectional study." The Lancet online. https://doi.org/10.1016/ S0140-6736(12)60240-2

Booth, R. and Duncan, P. (2020). More than 16,000 people in UK care homes have died from coronavirus. The Guardian, 16 June 2020.

Booth, R. (2020). Covid-19: risk of death in UK care homes 13 times higher than in Germany. Source : London School of Economics, The Guardian, 28 June 2020.

Centre for Policy on Ageing (1990). Community Life: A Code of Practice for Community Care. London: Centre for Policy on Ageing.

Challis, D., Hughes, J., Xie, C. and Jolley, D. (2013). An examination of factors influencing delayed discharge of older people from hospital, International Journal of Geriatric Psychiatry, 29 (2), pp. 160-168.

Clark, H., Dyer, S. and Horwood, J. (1998). That bit of help: The high value of low level preventative services for older people, Bristol, UK: Policy Press.

Department of Health (DoH). (1989). Caring for People: Community Care in the next decade and beyond. $\mathrm{Cm} 849$, London: HMSO.

Eenoo, L V., Declercq, A., Onder, G., Finne-Soveri, H., Garms-Homolová, V., Jónsson, P., Dix, O., Smit, J., van Hout, H. and van der Roest, H. (2016). European Journal of Public Health, 26(2) April 2016, pp. 213-219.

Esping-Andersen, G. (1990). The Three Worlds of Welfare Capitalism. Cambridge: Polity Press. European Commission (2018). 2018 Ageing Report: Policy challenges for ageing societies. 25 May 2018, EU Commission, Brussels.

Eurostat (2018). Eurostat Regional Yearbook 2018, Luxembourg: European Commission. (www.europa.eu.int/comm/eurostat) Available from: https://ec.europa.eu/eurostat/web/ products-statistical-books/-/KS-HA-18-001 [accessed 06.10.2020].

Ford, D. and Stepney, P. (2003). Hospital discharge and the citizenship rights of older people: will the UK become a test-bed for Eastern Europe? European Journal of Social Work, 6(3), pp. 257-273.

Glasby, J. (2003). Bringing down the 'Berlin Wall': the Health and Social Care Divide, British Journal of Social Work, 33 (7), pp. 969-975.

Glasby, J. (2003). Hospital Discharge: Integrating Health and Social Care, Abingdon, UK: Radcliffe Medical Press.

Glendinning, C., (2009). The Consumer in Social Care. In R. Simmons, M. Powell and I. Greener (Eds) The Consumer in Public Services: Choice, values and difference. Bristol: Policy Press.

Grell, O.P., Cunningham, A. and Jütte, R. (2017). Health Care and Poor Relief in 18th and 19th Century Northern Europe. New York: Routledge.

Hantrais, L. (2004). Family Policy Matters: Responding to Family Change in Europe, Bristol, UK: Policy Press.

Holloway, M. and Moss, B. (2010). Spirituality and social work. Basingstoke, UK: Palgrave Macmillan.

Kananen, J. (2014). The Nordic Welfare State in Three Eras: From Emancipation to Discipline, Farnham, UK: Ashgate. 
Karlsson, M., Mayhew, L., Plumb, R. and Rickayzen, B. (2006). Future Costs for Longterm Care: Cost projections for LTC for older people in the UK. Health Policy, 75 (2), pp. 187- 213.

Kharicha, K., Levin, E., Iliffe, S. and Davey, B. (2004). Social work, general practice and evidence-based policy in the collaborative care of older people: current problems and future possibilities, Health and Social Care in the Community, 12 (2), pp. 134-141.

Kluge, HHP (2020). Supporting older people during the COVID-19 pandemic is everyone's business. World Health Organisation Statement, 2 April 2020, Copenhagen, Denmark: Dr Hans Henri P. Kluge, WHO Regional Director for Europe.

Leathard, A. (ed) (2011). Inter-professional Collaboration: From Policy to practice in health and social care. New York: Routledge.

Leyland, A. and Kluge, HHP. (2020). European Public Health News. European Journal of Public Health, 30 (4) August 2020, pp. 842-844. Available from: https://doi.org/10.1093/ eurpub/ckaa151 [Accessed 07.10.2020].

Lymbery, M. (1998). Social Work in General Practice: dilemmas and solutions, Journal of Inter-professional Care, 12 (2), pp. 199-208.

Lymbery, M. (2012). "Social Work and Personalisation." British Journal of Social Work 42(4) pp. 783-792.

Means, R, Richards, S. and Smith, R. (2008). Community Care: Policy and Practice, $4^{\text {th }} \mathrm{ed}$, Basingstoke, UK: Palgrave Macmillan.

Mortimer, J. and Green, M. (2015). Briefing: The Health and Social Care of Older People in England, London: Age UK.

Payne, M. (1995). Social Work and Community Care. Basingstoke, UK: Macmillan.

Sapir, A. (2013). Globalisation and the Reform of European Social Models, Breugel Policy Brief, Brussels Available from: (www.slideshare.net/bluelucy/globalisation-and-the-reform-of-european-social-models) [accessed 01.10.2020].

Smith, P., McKeon, A., Blunt, I. and Edwards, N. (2014). NHS hospitals under pressure: trends in acute activity up to 2022. London: Nuffield Trust.

Spasova, S., Baeten, R., Coster, S., Ghailani, D., Peña-Casas, R. and Vanhercke, B. (2018). Challenges in long-term care in Europe. A study of national policies, European Social Policy Network (ESPN), Brussels: European Commission.

Stepney, P. (2014). "Prevention in Social Work: The final frontier?" Critical and Radical Social Work 2(3): 305-320.

Stepney, P. (2018). Theory and Methods in a Policy and Organisational Context: International Perspectives. In N. Thompson and P. Stepney (eds) Social Work Theory and Methods: The Essentials.pp. 44-62, New York: Routledge.

Stoop, A., Lette, M., Ambugo, E., Wirmann Gadsby, E., Goodwin, N., Macinnes, J., Minkman, M., Wistow, G., Zonneveld, N., Niipels, G., Baan, C. and de Bruin, S. (2020). Improving Person-Centredness in Integrated Care for Older People: Experiences from Thirteen Integrated Care Sites in Europe. International Journal of Integrated Care. Apr-Jun; 20(2): p. 16. Available from; doi: 10.5334/ijic.5427 [accessed 07.10.2020].

Taylor, B. (2005). Risk Management Paradigms in Health and Social Services for Professional Decision Making on the Long Term Care of Older People, British Journal of Social Work, 36 (8), pp. 1411-1429. 
Themessel-Huber, M., Hubbard, G. Munro, P. (2007). Frail older people's experiences and use of health and social care services, Journal of Nursing Management, 15 (2): pp. 222-229.

Thompson, N. and Thompson, S. (2005). Community Care. Lyme Regis, UK: Russell House. Thompson, N. (2019). Mental Health and Well-Being: Alternatives to the Medical Model: New York: Routledge.

Vamstad, J. (2016). Exit, voice and indifference - older people as consumers of Swedish home care services. Ageing \& Society, 36 (10), pp. 2163-2181.

Walker, A. (ed) (2005). Understanding quality of life in old age. Maidenhead, UK: Open University Press.

Wacquant, L. (2007). Territorial stigmatisation in an age of advanced marginality. Sage Publications and Thesis Eleven, 91, pp. 66-77.

Wistow, G. (1995). "Aspirations and Realities: community care at the crossroads." Health and Social Care in the Community 3(4), pp. 227-240. 